\title{
File din istoria psihologiei muncii din România
}

\author{
Nicolae Jurcău ${ }^{1}$ \\ Universitatea Tehnică din Cluj-Napoca
}

Marius Drugaş ${ }^{2}$

Universitatea din Oradea

\section{Introducere}

Istoria psihologiei muncii din România contine un amestec de fapte obiective, înregistrate, dovedite, sub care se ascund însă, mai ales pentru evenimentele de după al doilea război mondial, informații mai puțin cunoscute, controversate sau ambigue. Controlul strict al informațiilor în perioada anilor 1945-1989, încercările mai mult sau mai puțin reuşite de a minimaliza sau nega reuşitele unor personalități incomode, toate acestea fac ca munca de documentare să fie dificilă pentru cercetătorul care doreşte 0 imagine clară asupra acestei perioade. Informațiile relevante sunt amestecate adesea cu fragmente de limbaj de lemn, iar unele informații care ne-am aştepta să fie foarte clare sunt de fapt ambigue.

Acesta este motivul pentru care am structurat lucrarea noastră în două secțiuni. Prima este dedicată istoricului psihologiei muncii în România până în 1948, realizând o analiză separată a selecției şi orientării profesionale, psihotehnicii şi ergonomiei. Este, de asemenea, prezentată activitatea de cercetare desfăşurată de centrele universitare, precum şi câteva dintre lucrările cele mai cunoscute apărute în această perioadă. Pentru a da continuitate unor idei, am trecut însă, uneori, dincolo de 1948. Secțiunea se încheie cu o descriere scurtă a procesului „Marii finanțe", considerat în lucrarea noastră punct de cotitură. Cea de-a doua parte analizează perioada de după 1950 şi este relativ mai scurtă.

\footnotetext{
${ }_{1}^{1}$ Adresa de contact: Nicolae.Jurcau@dppd.utcluj.ro

${ }^{2}$ Adresa de corespondență:

mariusdrugas@gmail.com
}

\section{Psihologia muncii în România până la momentul 1948}

La începutul secolului al XX-lea, psihologia muncii s-a dezvoltat în câteva direcții largi (Beniuc \& colab., 1981): psihologia personalului, psihologia inginerească, raționalizarea muncii, psihologia economică, psihologia socială a muncii şi psihologia organizațională. În România, primele studii de psihologia muncii apar după primul război mondial, favorizate de redresarea economică.

Pentru a realiza o prezentare comprehensibilă, am încercat să grupăm contribuțiile la evoluția psihologiei muncii din această perioadă astfel: 1). aportul centrelor universitare; 2). activitatea primelor laboratoare psihotehnice şi a institutelor psihotehnice; 3). ergonomia în România; 4). publicații (cărți şi reviste) care au avut ecou în epocă sau mai târziu. Menționăm însă că logica prezentării a determinat uneori 0 suprapunere a direcțiilor prezentate.

\section{Aportul centrelor universitare}

În România, psihologia începe să se constituie ca disciplină independentă, cu caracter experimental, la puțin timp după ce ea începe să se dezvolte ca ştiință experimentală pe plan mondial. Activitatea de cercetare în domeniul psihologiei muncii $\mathrm{s}-\mathrm{a}$ desfăşurat $\mathrm{cu}$ preponderență în centrele universitare din laşi, Bucureşti şi Cluj-Napoca, unde au fost înființate, pe rând, primele laboratoare de psihologie experimentală din România. Pionierii psihologiei experimentale din România - E. Gruber, C. Rădulescu-Motru, F. ŞtefănescuGoangă - îşi fac ucenicia în primul laborator de psihologie experimentală, al lui W. Wundt, înființat în 1879 la Leipzig. Ca sa devină ştiințifică, psihologia s-a dezvoltat inițial ca o „știință naturală”, pe modelul biologiei sau fiziologiei, devenind experimentală, apoi lărgindu-şi câmpul de activitate spre cele mai 
variate aplicații, devenind, pe lângă o ştiință teoretică, şi o ştiință aplicată, chiar o psihotehnică. La noi, etapa aceasta n-a fost atinsă plenar decât între cele două războaie mondiale, deci după Unirea din 1918.

În 1906 Constantin Rădulescu-Motru înființează laboratorul de psihologie experimentală la Universitatea din Bucureşti, care se va dezvolta însă în condiții destul de vitrege, legate mai ales de dificultatea obținerii fondurilor.

Atraşi de perspectiva aplicațiilor practice ale psihologiei, F. Ştefănescu-Goangă şi C. Rădulescu-Motru reuşesc să obțină aprobarea Ministerului Muncii pentru înființarea unor laboratoare psihotehnice în Cluj şi Bucureşti (Bejat, 1972). La Bucureşti, Constantin Rădulescu-Motru înființează în 1930 Secția de Psihotehnică a Laboratorului de psihologie de la universitate; în acelaşi an, se constituie Societatea Psihotehnică Universitară, care publică „Revista de psihologie experimentală şi practică”. Primul număr al revistei, din 1931, cuprinde o amplă descriere a conferinței de raționalizare şi psihotehnică de la Berlin. Laboratorul din Bucureşti traduce şi experimentează testele Army Alpha şi inițiază studii de teren privind muncitorii în industria petrolieră din Valea Prahovei şi din fabrica de ciment de la Gura Honț (Roşca, 1967).

În 1922, se înființează la Cluj-Napoca Institutul de psihologie experimentală comparată şi aplicată, sub conducerea lui Florian Ştefănescu-Goangă. Printre scopurile specialiştilor care lucrau la institut se numără adaptarea şi elaborarea de teste şi chestionare psihologice, precum şi construirea unor aparate psihotehnice. Studiile realizate aici au fost publicate începând din 1929 în revista „Studii şi cercetări psihologice”, care a apărut până în 1945.

Ştefănescu-Goangă face demersuri pentru înființarea unei secții de psihologie aplicată, deoarece, după cum susținea în 1923, pentru pregătirea ştiințifică a înființării de oficii de orientare şi selecție profesională este nevoie de etalonarea testelor şi adaptarea materialului de cercetare pentru conditiile din România (apud Roşca \& Bejat, 1976). Despre această activitate vorbeşte cu deosebită considerație Nicolae Mărgineanu (1931), apreciind că ea a devenit cu adevărat ştiințifică, nu numai didactică (apud Bejat, 1972).

Ralea şi Botez (1958, p. 700) critică însă cercetările lui Ştefănescu-Goangă şi a colaboratorilor săi de la Cluj, afirmând că acestea conduc "către 0 psihologie experimentală bazată pe teste [...]. Şcoala de la Cluj a făcut abuz de întrebuințarea testelor, utilizate uneori fără prea mult discernământ, ducând la rezultate convenționale şi dorite de mai înainte". Aceeaşi critică a utilizării excesive a testelor este adusă şi unora dintre lucrările publicate de Ştefănescu-Goangă, („Selecționarea capacităților şi orientarea profesională”, „Măsurarea inteligenței”), lucrărilor lui Liviu Rusu („Aptitudinea tehnică şi inteligența practică”, „Selecția copiilor dotați”) sau Alexandru Roşca („Măsurarea inteligenței şi debilitatea mintală”, „Psihopatologia deviaților mintali”).

Una dintre direcțiile spre care s-a concentrat atenția specialiştilor în psihologia muncii a fost, aşadar, aceea a orientării profesionale, care devenise problemă curentă în România. În timp ce în străinătate orientarea profesională era susținută mai ales de cei care lucrau în industrie, la noi problema este ridicată de centrele universitare, în special de cele din Cluj şi Bucureşti. Înființarea laboratoarelor de psihologie experimentală în centrele mentionate a permis derularea primelor studii în domeniul psihologiei muncii şi orientării profesionale. Efortului personalului universitar i se adaugă activitatea centrelor de cercetare ale ministerelor şi Academiei, legate de creşterea productivității muncii sau de organizarea producției.

\section{Activitatea primelor laboratoare psihotehnice şi a institutelor psihotehnice}

În 1925 se înfiiințează primul laborator psihotehnic la Societatea de Tramvaie Bucureşti, condus de P. Tomescu. Investigațiile erau realizate $\mathrm{cu}$ probe individuale, care acopereau majoritatea funcțiilor psiho-fiziologice specifice vatmanilor (Pitariu, 1978). Lucrările şi rezultatele obținute au fost publicate într-un raport intitulat „Contribuții la studiul examenelor psihotehnice. Selecționarea profesională a conducătorilor de vehicule, manipulanți de tramvaie, şoferi şi mecanici de locomotive", prezentat la un congres național din 1930. Evoluția laboratorului a înregistrat însă un regres în anii următori.

Din 1927, examinările psihologice încep să fie utilizate în aviație, de către Centrul Medical Aeronautic de la Pipera, condus de V. Atanasiu, evaluându-se timpul de reacție, 
aprecierea spațială, emotivitatea, echilibrul static, rezistența la amețeală. După al doilea război mondial, constatându-se că profesiogramele prezentau analitic factorii psihici implicați în activitatea de zbor, neglijând factorii temperamentali, se trece la o reanaliză a caracteristicilor psihologice implicate (Holban, 1970).

Tot în 1927 este înființat, la inițiativa Uniunii Generale a Industriaşilor din România (U.G.I.R.), Institutul Românesc de Organizare Ştiințifică a Muncii (I.R.O.M.). Primul număr al buletinului I.R.O.M., apărut în acelaşi an, deschidea posibilitatea discuțiilor asupra problemelor legate de organizarea ştiințifică a muncii, şi era totodată un mijloc de informare asupra realizărilor din România şi din străinătate (Holban, 1970).

În 1935 se înființează Serviciul Psihotehnic al Casei Centrale a Asigurărilor Sociale pentru Prevenirea Accidentelor de Muncă, condus de G. Bontilă.

Primul laborator de selectie a personalului pentru transporturi a fost înființat în 1936, fiind organizat similar laboratoarelor franceze. Bateria de teste permitea înregistrarea a aproximativ 30 de parametri; din păcate însă evaluarea izolată a aptitudinilor nu putea să constituie un indiciu al eficienței lor în activitatea de muncă. După al doilea război mondial, Laboratorul Central al Căilor Ferate îşi reia activitatea, în 1952, prin consolidarea bazei metodologice. În 1954 sunt înființate şase laboratoare regionale (Bucureşti, Braşov, Cluj, Craiova, laşi şi Timişoara). Spre deosebire de perioada anterioară, metodologia de culegere a datelor presupunea şi analiza randamentului şi comportamentului candidatului la locul de muncă, pentru cei din producție. Examenul de laborator era de asemenea modificat, fiind înlocuite în cele mai multe cazuri testele scrise cu examinarea cu ajutorul aparatelor.

În cadrul armatei, orientarea şi selecția profesională se efectuau prin Laboratorul psihotehnic de pe lângă Şcoala pregătitoare de ofițeri de geniu, condus de A. Chiappella.

În perioada interbelică şi imediat după aceea au fost organizate laboratoare psihotehnice uzinale; Industria Aeronautică Română (I.A.R.), Uzinele şi Domeniile Reşița şi Uzinele Astra Braşov posedau laboratoare organizate sub conducerea lui Nicolae Mărgineanu şi T. Arcan (Beniuc \& colab., 1981). Mărgineanu (1942) prezenta criteriile de organizare a selecției noilor lucrători prin teste creion-hârtie şi teste de performanță (apud Holban, 1970).

Activitatea laboratoarelor menționate şi a IROM au creat un curent de opinie favorabil noilor idei, susținând crearea unor institute pe această linie. În 1936 se publică „Legea pentru pregătirea profesională şi exercitarea meseriilor", care prevedea înființarea institutelor psihotehnice din Bucureşti, Cluj, Iaşi şi Cernăuți, precum şi a 15 oficii de orientare profesională.

Institutul din Cluj, de exemplu, avea în subordine oficiile din Cluj, Oradea, Arad, Timişoara, Sibiu şi Braşov (Jurcău, 2003). Comparând lucrările institutelor, Mărgineanu afirma că acelea din Cluj sunt mai bogate şi mai numeroase (apud Petroman, 2002). Institutele au avut însă o viață efemeră, fiind desființate în 1940 şi înlocuite cu două laboratoare psihotehnice, la Bucureşti şi Sibiu, care au dispărut la rândul lor, împreună cu oficiile de orientare, câțiva ani mai târziu. Cu toate că au funcționat foarte puțin, institutele inițiale au fost bine dotate $\mathrm{cu}$ aparatură şi publicații de specialitate.

Din păcate însă datele obținute erau privite mai ales sub aspectul lor cantitativ. Deja în 1935, Rădulescu-Motru critica unilateralitatea concepțiilor psihotehnicienilor, care luau în considerare numai factorii psihologici (în special cei aptitudinali), neglijându-i pe cei sociali (apud Bejat, 1972).

Raportarea la personalitate se realiza sporadic (Holban, 1970). Activitatea psihologilor se baza mai ales pe teoriile clasice ale aptitudinilor, această deficiență făcând ca oficiile de orientare să realizeze mai degrabă acțiuni cu caracter de selecție profesională (Jurcău, 1980). Acest fapt a dus la înmulțirea preocupărilor pentru lărgirea sferei orientării profesionale, pentru a fi realizată încă de la nivelul şcolilor. În „Jurnalul de psihotehnică” sunt descrise de exemplu acțiuni ale institutelor psihotehnice îndreptate spre examinarea psihologică a copiilor din şcolile primare sau a studenților (mai ales în Cluj şi Bucureşti).

În general, cercetările de psihologia muncii realizate în țara noastră înainte de 1944 priveau selecția şi orientarea profesională, încadrându-se în limitele psihotehnicii, cu toate aspectele ei pozitive şi negative (Beniuc \& colab., 1981).

În această perioadă de restructurare, activitatea de selecție şi orientare a continuat mai ales în domeniul transporturilor, unul dintre primele în care $\mathrm{s}$-au modificat metodele 
examinării psihologice. Optica îngustă a psihotehnicii a fost depăşită, fapt evidențiat şi pe plan internațional şi prin schimbarea denumirii Asociației Internaționale de Psihotehnică, adoptându-se încă din 1939 denumirea de psihologie aplicată.

După 1944, depăşind îngustimea psihotehnicii, cercetările s-au îndreptat spre aspectele moderne ale procesului muncii, cercetările fiind realizate de Institutul de Psihologie al Academiei şi publicate mai ales în Revista de psihologie. Colectivul de psihologie socială al acestui institut întreprinde cercetări în Fabrica de Confecții şi Tricotaje Bucureşti şi în întreprinderile miniere, forestiere şi agricole din Berevoeşti-Muscel, investigând factorii psihosociali ai randamentului muncii (Herseni, 1969). Printre temele abordate menționăm munca țesătoarei, a strungarului, munca la banda rulantă, comunicarea în procesul muncii, aplicațiile psihologiei în agricultură.

\section{Ergonomia în România}

Premisele dezvoltării acesteia sunt marcate de cercetările de medicina muncii, fiziologia şi psihologia muncii, igiena şi protecția muncii. După 1944, au apărut probleme legate de introducerea unor noi tehnologii, de trecerea la automatizare, punându-se mai mult accent pe studiul interacțiunilor dintre om şi mediul său de muncă. Cu alte cuvinte, se ajunge la unificarea a două direcții considerate până acum divergente: adaptarea omului la munca sa (selecție, orientare, formare), respectiv a muncii la om (ergonomie, psihologie inginerească).

$\mathrm{Cu}$ toate că probleme de ergonomie au fost parțial atinse de cercetările institutelor psihotehnice, despre ergonomie ca ştiință complexă a muncii nu putem să vorbim decât din 1967, când se înființează Centrul de perfecționare a pregătirii cadrelor de conducere din întreprinderi, care a început să predea cunoştințe de ergonomie. Primul simpozion de ergonomie din România are loc în 1968, la Bucureşti, iar din 1971 sunt organizate în cadrul CEPECA primele cursuri de formare în acest domeniu. Trei ani mai târziu se organizează prima Conferință Internațională de Ergonomie de la Bucureşti, care a arătat că România dispune de un mare potențial de cercetare în domeniul psihologiei inginereşti şi că există numeroşi specialişti. Pe de altă parte, este adevărat însă că specialiştii aveau o pregătire foarte diversă, existând „o accentuată tendință la psihologi de a discuta şi lucra cu alți psihologi, iar la medici de a lucra şi discuta cu alți medici în rezolvarea problemelor de ergonomie" (Jurcău, 2003, p. 25).

Manolescu (1988) enumeră o serie de critici la adresa studiilor de ergonomie din perioada menționată, identificând şi o serie de cauze ale preocupărilor reduse în acest domeniu. $\mathrm{Cu}$ toate progresele înregistrate, se mențineau o serie de neajunsuri legate în primul rând de lipsa unui cadru organizatoric adecvat, corelat $\mathrm{cu}$ obiectivele cercetării ergonomice; de asemenea, nu s-a realizat cu adevărat 0 convergență a domeniilor de cercetare care participă la constituirea ergonomiei, şi multe dintre studii aveau un caracter unilateral, rezolvând doar anumite aspecte ale activității omului în procesul muncii. Dintre cauzele nivelului scăzut al preocupărilor pentru acest domeniu, sunt enumerate: numărul mic al specialiştilor, calificarea insuficientă a personalului, presiunea sarcinilor curente, modul de determinare şi interpretare a eficienței studiilor ergonomice.

\section{Publicatiii care au marcat psihologia muncii}

Probleme ale organizării producției şi muncii sunt amplu dezbătute în reviste de specialitate: Jurnalul de Psihotehnică (19371941) - editat de Institutul de Psihotehnică din Bucureşti, Revista de Psihologie Experimentală şi Practică (1931-1933) Bucureşti, Analele de Psihologie (1934-1944) Bucureşti, Revista de psihologie teoretică şi aplicată (1938-1949) - Cluj. Se publică articole privind principiile psihotehnicii, problema oboselii etc., scrise de autori români sau de colaboratori din străinătate.

Printre lucrările publicate în această perioadă menționăm: „Selecția capacităților şi orientarea profesională" (Ştefănescu-Goangă, 1929) [de fapt o dezvoltare a unei conferinte ținute în cadrul Institutului Social Român; lucrarea are meritul de a fi deschis drumul aplicațiilor practice ale psihologiei în România]; "Teste pentru măsurarea funcțiilor mintale" (Ştefănescu-Goangă şi Roşca, 1935); „Orientarea profesională în industria metalurgică” (Arcan, 1940); „Aptitudinea tehnică” (Peteanu, 1942); „Psihotehnica” (Mărgineanu, 1943) (apud Pitariu, 1978).

Secția de orientare profesională şi psihometrie a fostului Institut Psihotehnic „C. 
Rădulescu-Motru" din Bucureşti a publicat primele profesiograme psihologice, în 1939. Conceput conform principiilor lui Albert Hoth, volumul cuprindea, în pliante, 114 profesiograme pentru uzul oficiilor de orientare profesională şi al şcolilor cu caracter profesional. În fiecare profesiogramă erau specificate 26 de însuşiri psihice, indicându-se gradul de importanță al fiecăreia (absolut necesară, necesară, de dorit). Volumul nu a fost lipsit de critici: a fost neglijată interdependența factorilor psihici, în favoarea unui punct de vedere excesiv de analitic; însuşirile specificate erau selectate mai ales din categoria aptitudinilor, neglijându-se alte laturi ale personalității (Holban, 1970).

Mărgineanu (1943) analizează astfel de profesiograme, concluzionând că ele lucrează cu un număr prea mare de variabile, care nici măcar nu sunt cele mai importante şi care ignoră rezultatele analizelor factoriale. El afirma că „veacuri de-a rândul [...] omul a trebuit să se acomodeze sarcinii şi uneltei. E meritul organizării ştiințifice a muncii de a fi inversat problema." (apud Holban, 1970, p. 29). În calitate de consilier tehnic, Mărgineanu elaborează profesiogramele psihologice pentru posturi din cadrul Industriei Aeronautice Române şi Uzinele şi Domeniile Reşița, în vederea selecției profesionale a muncitorilor. Demersul lui este riguros, pornind de la analiza sarcinilor şi stabilind însuşirile psihice necesare, în funcție de solicitarea implicată de fiecare operație. Autorul restrânge numărul aptitudinilor specificate, introducând în schimb trăsături temperamentale şi caracteriale, precum şi variabile legate de starea de sănătate.

În paralel cu activitatea lui Mărgineanu, Institutul Psihotehnic din ClujNapoca elaborează 150 de monografii profesionale, în trei volume, primele două lucrate de G. Cotul, S. Cupcea, M. Peteanu şi A. Roşca, iar al treilea de V. Lacrițeanu, M. Peteanu şi A. Roşca. Acelaşi institut elaborează două lucrări de sinteză, pe aceeaşi linie: „Tabele cu cerințele psihologice ale profesiunilor" (A. Roşca şi M. Peteanu) şi „Tabele cu contraindicațiuni medicale ale profesiunilor" (D. Lacrițeanu şi M. Peteanu) (apud Holban, 1970). Comparativ cu încercările celor din Bucureşti, colectivul din Cluj are meritul de a acorda importanță şi altor factori decât aptitudinilor. Cu toate că lucrările sunt depăşite, datorită schimbărilor survenite de-a lungul anilor în conținutul meseriilor, ele reprezintă un pas important în cunoaşterea profesiilor, constituind puncte de plecare pentru numeroase studii (Jurcău, 1980).

Critica generală adusă tuturor publicațiilor este aspectul analitic excesiv şi punctul de vedere static din care este privită personalitatea. Ele nu evidențiază importanța dominantelor psihice, faptul că personalitatea este o unitate, o organizare internă. Dincolo de critici, aceste monografii alcătuiesc totuşi prima încercare de analiză a posturilor, contribuind la organizarea activității de orientare profesională şi a celor de selecție.

\section{Procesul „Marii finanțe”}

Anul 1948 aduce o grea lovitură psihologiei din România. Jurnalul Național din 5 februarie 2008 relatează pe scurt procesul „Marii finanțe”. La sfârşitul lunii octombrie, douăsprezece persoane au fost acuzate pentru încercarea de "subminare a regimului democrat-popular". Conform unui articol publicat pe site-ul CNSAS de către Cristina Anisescu, procesul nu fusese altceva decât o înscenare judiciară pentru a "stârpi” ultimele rămăşițe legionare. Lista complotiştilor îi cuprindea pe Alexandru Popp (fost director general la Uzinele şi Domeniile Reşița), Ioan Bujoiu (proprietar al mai multor mine de cărbune de pe Valea Jiului), inginerii Balş şi Gheorghiu (care ocupaseră posturi de conducere în industria petroliferă şi minieră), Nicolae Mărgineanu (pentru „atitudinea democratică" şi legături cu americanii, cărora le-ar fi furnizat informații despre uzinele din Reşița), George Bontilă şi alții. Aceştia au fot învinuiți de fapte pe care este imposibil să le fi realizat, în condițiile controlului strict al comunismului din România. Procesul a durat foarte puțin, la 2 noiembrie dându-se citire sentinței. Nicolae Mărgineanu era condamnat la 25 de ani de muncă silnică.

Jurnalul Național publicase cu o săptămână mai devreme (30 ianuarie 2008) un interviu cu fiul psihologului Nicolae Mărgineanu, Nicolae D. Mărgineanu. Mărgineanu tatăl fusese bursier al fundației Rokefeller în Statele Unite, iar la întoarcere a fost unul dintre cei care au fondat psihologia muncii în România, conducând laboratoare în centrele industriale Reşița, Bucureşti, Galați etc. Va intra treptat în dizgrația autorităților, în septembrie 1947 fiind "comprimat" de la universitate (poziția sa a fost scoasă din organigramă). Va fi arestat un an mai târziu, în procesul „Marii finanțe". Valiza era deja pregătită, îşi aminteşte Nicolae D. Mărgineanu. 
A urmat o perioadă de restrişte pentru familie; în speranța că persecuțiile împotriva familiei vor înceta, soția a divorțat, dar nu s-a întâmplat nimic pozitiv.

Familia a reuşit să-I vadă în 1954, pentru câteva momente, când era adus ca martor într-un alt proces. Eliberarea a venit în 1964, dar nu a povestit foarte multe familiei despre detenție, traumatizat de cei 16 ani la Jilava, Gherla, Malmaison, Piteşti şi Aiud. Abia în 1971 i se permite să revină la Catedra de Psihologie a universității clujene. Apare în această perioadă „Selecția şi orientarea profesională" (1972). Va muri în 1980, din cauza unui cancer la colon.

\section{Psihologia muncii în România după 1948}

Perioada dintre 1940 şi 1950 a fost una dificilă pentru psihologie, fiind marcată de transformări sociale, opresiuni politice şi confuzii ideologice. După al doilea război mondial, orientarea profesională a continuat să existe ca preocupare, deşi nu au existat instituții special create care să-i asigure un suport ştiințific.

Recuperarea capacității de muncă, reintegrarea în viața socială a persoanelor cu deficiențe a fost până în 1950 o preocupare a serviciilor medicale şi a oficiilor de orientare profesională. În 1951 se înființează Institutul de Expertiză şi Recuperare a Capacității de Muncă, care avea rol metodologic, de orientare şi control. Institutele psihotehnice din Bucureşti, Cluj şi laşi fuseseră transformate aproape imediat după înființare în institute de cercetări ştiințifice pentru recuperarea deficiențelor mintale, senzoriale şi motorii. A urmat însă desființarea, chiar în anul înființării, a institutelor din Cluj şi laşi, fiind menținut doar cel din Bucureşti. Printre scopurile comisiilor teritoriale (înlocuite în 1957 cu serviciile şi secțiile de expertiză) se număra şi asigurarea unui câmp de prestație suficient pentru a face posibilă cunoaşterea locurilor de muncă (Burloiu, 1997).

După 1950, se formează însă în jurul unor personalități cunoscute mici colective de lucru; un astfel de exemplu este colectivul de psihologie din Cluj, care sub îndrumarea lui Alexandru Roşca a reuşit să inițieze şi să finalizeze cercetări în domenii extrem de diverse. Conform scopului lucrării noastre, le menționăm mai ales pe cele referitoare la adaptarea muncitorilor la profesie, realizate în beneficiul unor organizații (Combinatul
Siderurgic Galați, Combinatul Textil şi Centrul Teritorial de Calcul din Cluj-Napoca) şi finalizate cu o serie de studii şi monografii, unele publicate, altele predate beneficiarilor (Berar, Jurcău \& Pitariu, 2006). În general, erau abordate probleme de selectie şi formare a personalului, organizarea muncii, controlul calității produselor, prevenirea accidentelor etc.

În 1964 se înființează Asociația Psihologilor din România, conferințele naționale din 1966, 1968 şi 1971 având şi secțiuni de psihologia muncii. În 1970 are loc primul simpozion de psihologia muncii, care printre altele identifica principalele probleme $\mathrm{cu}$ care se confrunta psihologul industrial din România. Tematica simpozionului a fost diversă: orientare, selecție şi repartizare profesională, psihologie inginerească, psihologie socială industrială şi organizațională (Pitariu, 1978).

Din 1968, se reînfiintează laboratoarele de psihologie industrială pe lângă marile uzine şi întreprinderi (Reşița, Săvineşti, Tehnofrig Cluj, Someşul-Cluj etc.) (Beniuc \& colab., 1981). În 1976 existau peste 74 de astfel de laboratoare. După cum reiese dintr-un interviu luat lui N. Mărgineanu de către $V$. Lăscuş, situația era considerată satisfăcătoare deoarece s-a găsit înțelegere din partea conducerii organizațiilor pentru dotarea minimală cu echipamente, teste, chestionare şi fişe; în acelaşi timp însă Mărgineanu sublinia că elaborarea acestor materiale de către un institut central (cum erau Institutele Psihotehnice) ar fi scăzut costurile de 3-5 ori (apud Petroman, 2002).

În aceeaşi ordine de idei, Bogathy (1975) considera că intervenția cea mai eficientă a psihologiei o constituie activitatea directă a psihologului industrial într-o întreprindere. În acest scop, descrie amănunțit organizarea laboratorului uzinal (înființare, dotare, personal), problematica laboratorului (selecția, orientarea şi formarea profesională, integrarea socioprofesională, cercetarea climatului psihosocial, a motivației, a accidentelor de muncă etc.), elaborarea psihoprofesiogramei, metodele de examinare, desfăşurarea examenului psihologic şi profesiograma profesiunii de psiholog industrial. Laboratorul uzinal înființat la Reşița, în 1968, nu mai avea însă nimic comun cu psihotehnica anilor 1938.

Seria monografiilor şi a manualelor de psihologia muncii continuă cu „Psihologia muncii industriale” (Roşca, 1967); „Psihologia 
muncii” (Pufan, 1968); „Probleme de psihologia muncii” (Holban, 1970); „Selecția şi orientarea profesională" (Botez, Mamali şi Pufan, 1971), „Ghid ergonomic” (PopescuNeveanu, Mirea, losif şi Ene, 1971) (apud Beniuc \& colab., 1981). Psihologia muncii era îndreptată spre orientarea, repartizarea şi selecția profesională, formarea cadrelor în industrie, probleme psihosociale (absenteism, fluctuație etc.), probleme de ergonomie şi psihologie inginerească (prevenirea oboselii şi a accidentelor), informarea specialiştilor.

Atenția acordată analizei muncii ca punct de plecare pentru activitatea psihologilor se reflectă în numărul mare de profesiograme şi monografii profesionale psihologii din institutele de cercetări sau de către cei din producție (Peteanu, Jurcău, Samu, Ozunu) (Beniuc \& colab., 1981).

Caracteristică acestei perioade este apariția culegerilor în care membrii catedrelor de psihologie din țară îşi publicau cercetările; de exemplu, cadrele didactice din Cluj publicau în 1973 lucrarea „Elemente de ergonomie pentru lucrătorii din industrializarea şi prelucrarea lemnului". Pe plan internațional, încep să fie publicate o serie de articole de prestigiu din domeniul psihologiei muncii (apud Berar, Jurcău \& Pitariu, 2006).

Profesorul Roşca a coordonat şi colectivul Filialei din Cluj a Academiei; colectivul de psihologia muncii cu care a lucrat a fost reprezentat de N. Jurcău, I. Latiş, H. Pitariu, V. Samu, I. Czitrom, Reka Teodorescu şi M. Zăpârțan. Studiile realizate au fost publicate în reviste de specialitate („Revista de psihologie") şi au avut în acelaşi timp un accentuat caracter aplicativ, fiind inițiate contracte de cercetare cu organizații implicate în industria mineritului, industria grea şi de medicamente.

Din 1975, începe acțiunea de dizolvare a psihologiei româneşti, multe dintre cadrele didactice fiind disponibilizate şi repartizate spre alte locuri de muncă. Catedrele de psihologie din țară au fost absorbite de diverse alte catedre, lichidânduse anii de studii existenți.

După evenimentul meditației transcedentale, din 1982, Institutul de Psihologie al Academiei este desființat abuziv. Psihologia a fost aruncată „la coşul de gunoi” (Petroman, 2002, p. 292); desființarea facultăților de psihologie şi scoaterea acestei discipline din programe şcolare au încetinit ritmul dezvoltării acesteia.
După 1989, se reînființează facultățile de psihologie din Bucureşti, Cluj şi laşi şi se înființează facultăți noi în Timişoara, Oradea, Constanța, Petroşani ş.a.

\section{Bibliografie}

Bejat, M. (1972). Geneza psihologiei ca ştiință experimentală în România. Bucureşti: Editura Didactică şi Pedagogică.

Beniuc, M., Chircev, A., Pavelcu, V., \& Roşca, A. (1981). Sinteze de psihologie contemporană. Psihologia muncii industriale. Bucureşti: Editura Republicii Socialiste România.

Berar, I., Jurcău, N., \& Pitariu, N. (2006). Profesorul Alexandru Roşca şi cercetarea psihopedagogică departamentală. În I. Berar (coord.), Alexandru Roşca (1906-1996): omul, savantul, creatorul de şcoală (pp. 119132). Bucureşti: Editura Academiei Române.

Bogathy, Z. (1975). Îndreptarul psihologului industrial. Bucureşti: Editura Ştiințifică şi Enciclopedică.

Burloiu, P. (1977). Managementul resurselor umane. Bucureşti: Editura Lumina Lex.

Herseni, T. (coord.) (1969). Laboratorul uzinal. Bucureşti: Editura Ştiințifică.

Holban, I. (1970). Probleme de psihologia muncii. Bucureşti: Editura Ştiințifică.

Jurcău, N. (coord.) (2003). Psihologie inginerească (ed. a II-a). Cluj-Napoca: U.T. Pres.

Jurcău, N. (1980). Aptitudini profesionale. ClujNapoca: Editura Dacia.

Manolescu, A. (1988). Managementul resurselor umane. Bucureşti: Editura RAl.

Petroman, P. (2002). Afirmarea psihologiei. Direcții şi orientări în cadrul psihologiei explicite. Timişoara: Editura Eurostampa.

Pitariu, H. (1978). Psihologie industrială. Lecții. Universitatea Babeş-Bolyai Cluj-Napoca, Facultatea de Istorie-Filosofie, uz intern.

Ralea, M., \& Botez, C.I. (1958). Istoria psihologiei. Bucureşti: Editura Academiei Republicii Populare Române.

Roşca, A. (red.) (1967). Psihologia muncii industriale. Bucureşti: Editura Academiei Republicii Socialiste România.

Roşca, A., \& Bejat, M. (1976). Istoria ştiințelor în România. Psihologia. Bucureşti: Editura Academiei.

*** Jurnalul Național, 30 ianuarie 2008.

*** Jurnalul Național, 5 februarie 2008.

http://www.cnsas.ro/Publicatii/memoriam.pdf. 